\begin{abstract}
:
In a climate riven by national insecurities, anti-immigration movements and competing visions of a post-Brexit future, this paper examines the contentious space multiculturalism has inhabited in $21^{\text {st }}$-century British choreography. It analyses acclaimed works by Akram Khan and Lloyd Newson to explore starkly differing perspectives on cultural diversity in the UK. Khan's contribution to the London 2012 Olympics Opening Ceremony (Abide with Me) emphasised the nation's post-imperialist and cosmopolitan profile. By contrast, Newson's contemporaneous work Can We Talk about this? (2011/12) was highly critical of current models of multiculturalism and in particular attitudes towards Islam. This paper compares the two choreographies using a theoretical framework that draws on both political thought and dance analysis, to evaluate their contributions to debates around culture, tolerance and diasporic identities and illustrate the broader entanglement between British dance and contemporary politics.
\end{abstract}

Key words: multiculturalism, hybridity, Britain, Akram Khan, Lloyd Newson, London Olympic Games

\title{
Akram Khan, Lloyd Newson, and the Challenges of British Multiculturalism
}

On $6^{\text {th }}$ July 2005, a day of jubilation when London had been awarded the 2012 Olympic Games, UK Prime Minister Tony Blair announced:

London is an open, multi-racial, multi-religious, multicultural city and rather proud of it. People of all races and nationalities mix in with each other and mix in with each other well. (cited in Tran 2005)

The following day, suicide bombers attacked civilians on public transport in central London, claiming fifty-two lives and leaving seven hundred injured. The incident, carried out by Islamist extremists who were middle-class UK citizens, sparked nationwide critical debates about the threats of terrorism and excavated deep-seated anxieties about multicultural society and British identity.

Fast-forward ten years, and in May 2016 Sadiq Khan was elected Mayor of London: the first Muslim mayor of a major Western city. One of his first acts was to vow to "take the arts as seriously as housing and crime” (cited in Razaq 2016), and online and television footage 
showed him side by side with British-Bangladeshi choreographer Akram Khan. They were backing the Big Dance Pledge, an inclusive large-scale biennial event initiated in 2006 and involving tens of thousands of dancers in more than forty countries worldwide. Their 2012 event had been the culmination of the Cultural Olympiad (Spratt, 2016; Big Dance Pledge, no date).

But eclipsing this image of harmonious diversity in the capital, just one month later on $16^{\text {th }}$ June, 41-year-old Labour MP Jo Cox, a supporter of the campaign to remain in the European Union and chair of the all-party parliamentary group for Friends of Syria, was killed in West Yorkshire by a white middle-aged man who according to eye-witnesses shouted "Britain first” before stabbing and shooting her (Booth et al. 2016). In court, when asked to confirm his identity, the attacker Thomas Mair stated that his "name is death to traitors, freedom for Britain” (Booth et al. 2016). A further week later, on $23^{\text {rd }}$ June 2016, Britain voted by 52\% to $48 \%$ to leave the EU, a monumental decision motivated primarily by issues of identity and opposition to migration. As Politics Professor John Curtice put it, the referendum was “primarily a debate about the kind of country Britain is and should be” $(2016,19)$.

The above examples serve as testimony to the impassioned critical debates, and at times violent incidents, revolving around culture, pluralism and diversity in the UK. As a German national living and working in Britain they have personally concerned me, as I have not only witnessed the events but been directly implicated in them. Formerly just 'one of many' working in the liberal climate of academia in one of the world's most multicultural cities, with relatively few reminders of my status as a foreign national, I have recently been forced to reflect on my situation as a result of the legal insecurities and xenophobic incidents following the 2016 referendum. All of a sudden I have been faced with my 'otherness' both in media discourses and at institutional level, with many universities seeking legal counsel on how to advise their European staff. Indeed, as a consequence of Brexit many EU citizens including myself have felt the need, somewhat reluctantly, to apply for 'permanent residence' and become the owner of a six-page "UK Residence documentation for a national of an EEA State” issued by the Home Office. The motives surrounding the referendum vote are admittedly highly complex as for example some immigrants, for various reasons, themselves voted to 'pull up the drawbridge' and restrict further inward migration. 
This article will investigate the contentious space that multiculturalism inhabits in $21^{\text {st }}$ century Britain through the lens of contemporary British choreography. I shall offer critical readings of works by renowned London-based choreographers Akram Khan and Lloyd Newson to examine starkly differing viewpoints. Multiculturalism, as Falcous and Silk remark $(2010,168)$, is variably seen as a solution to the question of national unity and integration, and conversely as a challenge to integrated and harmonious society. These different approaches, I shall argue, find artistic equivalents in Khan's and Newson's choreographies which articulate their responses to this controversial topic. Interestingly, migration played a part in both artists' own backgrounds with London-born Khan being of Bangladeshi descent and Lloyd Newson hailing from Australia.

Akram Khan's contribution to the London 2012 Olympic Games Opening Ceremony, which I shall hereafter call Abide With Me after the hymn to which it was set, was a global media spectacle seen as showcasing Britain's post-imperial, multicultural profile. Lloyd Newson's contemporaneous Can We Talk About This? (2011/12), a piece conceived for the theatre stage which toured internationally, was by contrast highly critical of contemporary British models of multiculturalism, especially where Islam is concerned. Both works, however, share commonalities in manifesting the entanglement of dance with UK politics and offering a contribution to the national discourse on multicultural and diasporic identities. They reveal ambiguous British attitudes towards diversity and nationalism, and having been choreographed in the early 2010s stand at the threshold of a significant period of political conflict in which the public celebration of multiculturalist values was met with a backlash. Comparing the two pieces side-by-side offers a valuable insight into how contemporary dance has situated itself politically in this debate and sought to influence opinion, whilst also raising important aesthetic questions about the different means of translating (contrasting) political viewpoints into choreographic language.

I shall begin by outlining the ideological and historical bases of contemporary debates about multiculturalism; in particular the key concepts of particularism, universalism and hybridity, and their respective relations to multiculturalist, enlightenment and cosmopolitan models of society and performance. Readers already acquainted with this theory might wish to skip this section, which is followed by in-depth readings of Khan's and Newson's choreographies set against the socio-political backdrop of their creation. My analysis will consider their intention, their perception by audiences, and the relation between their artistic discourses and 
broader political ones. ${ }^{1}$

\section{Particularism, universalism and hybridity}

Debates about the politics of multiculturalism are well rehearsed, although their complex philosophical and historical underpinnings are often glossed over in performance analysis. In its broadest sense, multiculturalism rests on the idea of cultural diversity within a given nation or group, and recognises that people are often marginalised or stereotyped on grounds of culture. The political goal of societies which embrace multiculturalism, either through legislation or government policy, is strictly speaking not equality among different groups (defined by religion, race etc.), but rather an acknowledgment that people of distinct cultures require different or special treatment to enable them to flourish. Multiculturalism is thus associated with a celebration of diversity allied to a belief that cultural identities provide meaning and value to individuals' lives; amounting to a politics of cultural recognition (Heywood 2012, 311 \& 319).

However, not all multiculturalism's supporters have the same view of precisely how a multicultural society will operate (or how it should be encouraged to do so). One significant strand of multiculturalism advocates particularism: the claim that each culture's particularities are a valuable inheritance to be maintained and protected, rather than subsumed within a universal legal or moral system or set of societal norms. In the particularist model, cultural attachment is primarily to one's own specific group (nationality, religion etc.), while a common culture encompassing all people may be neither possible nor desirable. This concept of multiculturalism in fact harks back to ideas first developed by cultural nationalists during the Romantic period. Writer and theorist Kenan Malik, a friend of Lloyd Newson's and one of around fifty people interviewed for the piece Can We Talk About This?, notes that multiculturalism draws heavily on Romantic notions of culture and identity (Malik 2007). 18 ${ }^{\text {th }}$-century German philosopher Johann von Herder was instrumental in advancing the view that differences in language and history result in distinct thought patterns

\footnotetext{
${ }^{1}$ I wish to extend my deepest gratitude and thanks to Luke Purshouse who was instrumental in discussing and at times questioning the complex theoretical and political issues raised by this topic, and without whose informed advice this would have been a different, and undoubtedly less differentiated, paper. Thanks also go to my former colleague Steve Jackson who provided me with relevant research articles on the Olympics, and two anonymous reviewers at Dance Research for their helpful comments.
} 
and ways of reasoning. Language may be seen as shaping human subjectivity, and Herder attached great importance to its role as the one of the principal ties individuating a nation, defining 'national character' and moulding national cultural traditions:

Has a people anything dearer than the speech of its fathers? In its speech resides its whole thought-domain, its tradition, history, religion, and basis of life, all its heart and soul. [...] The best culture of a people cannot be expressed through a foreign language; it thrives on the soil of a nation most beautifully. (Herder 1998)

For Herder, cultural practices are tied to the customs and traditions of particular places, which reflect their people's unique identity. We may thus speak of the cultural authenticity of, for example, works of dance, literature, or other artforms which capture the environment and essentially unchanging spirit of a national group (albeit perhaps adapted and modified over generations). ${ }^{2}$ Apposite examples in dance are folk forms which emerge from the lifeblood of specific communities and celebrate their uniqueness and difference from the cultural expressions of other groups or nations. Their political aims are typically conservative in the sense of preserving traditions and furthering a sense of local community. For example, folk dances such as the Spanish flamenco, Italian tarantella, or various regional varieties of the Bavarian Schuhplattler, express and symbolize membership of a specific kinship, country or region.

The particularist model in which cultures exist in the plural, and distinct from one another, stands in sharp contrast to the value system of the $18^{\text {th }}$-century Enlightenment, which spawned an alternative liberal model of society. On this account, all human beings share a common nature and culture - in the singular - is seen as a mechanism through which humanity can progress by the application of reason and science. ${ }^{3}$ In contrast with Romantic and particularist thought, the Enlightenment thus endorsed universalism and asserted the existence of transcultural values. It accordingly promoted a politics of rights, including universal citizenship and equality before the law, and believed that treating people 'differently' or discriminating between them was the cause of certain groups (such as women

\footnotetext{
${ }^{2}$ Herder's opposition to national cultures being diluted by cross-mixing with others essentially boils down to support for monoculturalism: cultures may exist in the plural, but not in the multiculturalist sense as the juxtaposition of different cultures within a nation is viewed as undesirable or dangerous.

${ }^{3}$ This of course was anathema to Herder who wrote that "it would be manifest stupidity to consider yourself to be the quintessence of all times and all people" (Herder, 1969, 182).
} 
or ethnic minorities) being marginalised or excluded. Taking this to its logical conclusion, someone's race, religion etc. should be irrelevant to their status as a citizen and our treatment of individuals should be difference blind (Heywood 2012, 315), paying no heed to any variations of cultural identity.

The enlightenment belief in a shared human nature and its downplaying of cultural difference has often been manifest in progressive forms of modern and contemporary dance, which seek to express and emphasize a desire for worldwide commonality, solidarity and understanding between all human beings. This is frequently underpinned by either an expressed or implicit belief in dance as a universal mode of communication which can circumvent the differences of verbal language. Throughout the $20^{\text {th }}$ century, dance was employed to advance various utopian conceptions of society based on universalist values of democracy, equality and human rights; take, for example, the following remark by Washington-based dancer Jacqueline Ashmedowa:

The language of dance is a universal language that unites expression and communication among all peoples on Earth, regardless of their origins, culture and colors. Our dancers are a [sic] real cultural and artistic messengers worldwide" (Ashmedowa, quoted in Bukai 2014).

However, the enlightenment ideals which underpin such beliefs in the universality of dance expression have come under attack from an array of contemporary viewpoints - including for instance postcolonial and feminist perspectives - for being insufficiently attentive to cultural diversity, Eurocentric, or even "hegemonic and dominatory” (Denby, 2005, 65). According to such critics, they prioritise Western rationality and liberal tenets (which they falsely assume to be 'universal') over and above the locally or culturally embedded values of other traditions, which are at best overlooked and at worst regarded as primitive or backward.

In recent decades, the renaissance of cosmopolitanism may be seen as a third model which has sought to overcome the alleged failings of both cultural particularism and enlightenment universalism. A term originally associated with the arguably elitist ideals of global citizenship and world government, the new version of cosmopolitanism is primarily based on the pursuit of "world openness" (Delanty 2006, 27) and recognition of the diverse and dialogic (as opposed to universal) ways in which social and political interactions are structured. It embraces the cultural pluralization resulting from migration and ethnic diversity, but in Salman Rushdie’s words “rejoices in mongrelization and fears the absolutism 
of the Pure” (1991, 394), eschewing any attempt to preserve separate cultures along Herderian lines.

The cosmopolitan model actively promotes hybridity: the intermingling of, and fluidity between, different cultural traditions to produce novel forms composed of elements of preexisting ones, but different from the mere sums of their parts. In so doing it rejects the particularist assertion of a fundamental need to belong to a specific group with a shared history, unique category of identity or community of descent. But equally it takes issue with those enlightenment intellectuals who would deny the importance of individuated culture in their quest for a universal human ideal. Sociologist and cultural theorist Homi Bhaba advocated hybridity as a "third space", a mode of articulation that disrupts hegemonic colonialist cultural discourses, and a liminal space (Bhabha 1996) in which new possibilities may be generated. Hybridity views the inclusion of previously marginalised voices as a basis for the production of new cultural meanings and abandons notions of cultural purity which have at times been used to legitimate hierarchies among cultures and discrimination against supposedly 'inferior' ones. ${ }^{4}$

In the performing arts, hybridity is the starting point for intermediality and intercultural theatre. Interculturalism is often contrasted favourably with multiculturalism on grounds that it encompasses "recognition of common human needs across cultures and of dissonance and critical dialogue within cultures" (Nussbaum 1997, 82), whilst opposing "the claim of identity politics that only members of a particular group have the ability to understand the perspective of that group” (ibid, 82). Patrice Pavis defines intercultural theatre as creating "forms drawing upon a more or less conscious and voluntary mixing of performance traditions traceable to distinct cultural areas. The hybridization is very often such that the original forms can no longer be distinguished” $(1996,8)$. Hybrid works and forms in dance manifest a shift away from "singular meanings, homogeneous movement styles or disciplinary norms towards multiplicity and complexity” (Butterworth, 2009, 249). With their resistance to mono-cultural frameworks and canonised dance genres, and incorporation of

\footnotetext{
${ }^{4}$ A range of informative and detailed texts in dance studies have drawn critically on Bhaba's work in the context of intercultural dance analysis (e.g., Cools 2015, Mitra 2015).
} 
techniques, styles and movements from different cultures, hybrid works are barometers of broader societal trends such as globalisation (cf. Rofli, 2012, 10). ${ }^{5}$

Hybridity has undeniably been increasingly relevant to $21^{\text {st }}$-century dance, especially in urban spaces where many recent choreographic developments have taken place. In the UK, hybrid styles are intimately associated with (among others) choreographers of Asian descent such as Akram Khan and Shobana Jeyasingh, who integrate South-East Asian with European, or more broadly Western, movement influences or vocabularies. Khan's reputation as an “embodiment of modern, multicultural Britain” (Mackrell 2012) was cemented when he was invited to choreograph part of the 2012 London Olympics Opening ceremony. The next section will offer a critical reading of this work in the context of the theory of interculturalism and the political framework within which it was produced.

\section{Akram Khan's Abide With Me for the London Olympics}

The sound of a gong being struck resounds through the arena. A large number of dancers grouped together, their torsos bent forwards, are lit up in orange-red colours and silhouetted against a massive yellow circular light symbolizing the sun. A sound resembling a human exhalation triggers the dancers to throw dust in the air simultaneously, keeping their arms extended upwards for a brief moment. Accompanied by sound of a heartbeat, the dancers part sideways into two groups, forming a corridor in the middle through which a young boy runs forwards. They bend backwards and smoothly sway from each foot to the other, like boxers, before transitioning into various unison formations; repeatedly throwing up their arms, jerking their heads and violently stomping their bare feet.

5 Yet despite its intentions to foster social cohesion and commonalities through performance, intercultural theatre has, particularly in its earlier 1980s manifestations, sometimes been criticised for the negligent or willful appropriation of non-Western cultures (see for instance Mitra 2015, 10). The merging of two traditions also runs a risk of devaluing both elements if they are juxtaposed or integrated inappropriately (Chin 1989, 168). The challenges faced by the artistic intercultural encounter are to negotiate the tension between upholding universal values and protecting of the voice of the 'other', and to balance the benefits of cross-cultural dialogue and critique with the "need to protect minorities” (Delanty 2006, 29). 
After the first few moments, the sounds give way to a hymn exploring life and death, Abide with $M e$, interpreted by British-Zambian singer Emile Sandé. Akram Khan himself - a soloist and counterpoint to the group of dancers, appears as the centre of a circle, which disperses into four smaller circles, then two rows, and eventually a single line performing movements in canon akin to a 'Mexican Wave'. The camera again focuses on Khan who walks towards the boy, executing a series of intricate hand movements, rolling his hands with the wrists held together. The boy embraces Khan, who carries him into the dancing group. The piece ends with all the performers kneeling in a heap, with the boy lifted into the air, arms reaching for the sky: a physical embodiment of one of the hymn's last lines, "Shine through the gloom and point me to the skies”.

Briefed by the artistic director of the Games, left-wing film maker Danny Boyle, to explore the theme of mortality, Khan's section of the Opening Ceremony was strategically inserted just before the athletes' parade. It hybridity manifests itself on various levels. The gong which heralds the piece is an instrument of originally Asian origin. The Christian hymn, to which the Muslim choreographer set his piece, was penned by Scottish Anglican Henry Francis Lyte in 1847. The compositional strategy owes much to Western contemporary dance but the movement mixes this form with elements of kathak and some positions which suggest martial arts influences. The dancers make highly extensive and expressive use of their arms in a style which is not often seen in contemporary dance, while the dramatic hand gestures (in particular the rolling of the hands with wrists together) are reminiscent of kathak mudras. ${ }^{6}$ The dynamics in Abide With Me - its rhythm and attack as well as its momentarily held poses - are similarly suggestive of kathak, but deployed in evocative rather than formal ways. In one section the dancers aggressively stamp their bare feet on the ground, a technique unusual in Western dance which hints at kathak's rhythmic footwork, although their execution of wild upper torso movements is opposed to the normally quite upright posture of traditional kathak. Moreover, while kathak is conventionally a solo form, the spatial organisation in Abide With Me strongly emphasises group dynamics, often (in keeping with previous Olympics displays) arranging the performers in patterns tailored to geometric perspectives of the stadium spectator and TV audience in bird's eye camera shots.

\footnotetext{
${ }^{6}$ I thank Stacey Prickett and Ann R David for their useful advice on the elements of kathak in this work.
} 
Abide With Me exemplifies Khan's compositional strategy of exploding the conventions of dance genres, which he uses not in a strictly academic sense but rather to point to looser significational possibilities, for example through improvisation: "In kathak so much is rigidity and maths in the form, and within that I try to find freedom” (quoted in Jaggi 2010). The merging of different technical and cultural elements, thus realised, typifies Khan's hybrid choreographic approach. In a 2014 interview he described how his body became 'confused' when he studied contemporary dance at tertiary level (in his twenties), after training in classical Indian dance from the age of seven. He reflected on what it meant for dance to lack purity in performance rendition: "What I realised it's not a fusion. I call the body transforming into a confusion [sic]. So it's a chaos, a sense of chaos, but it was an organic sense of chaos” (Akram Khan 2014).

As alluded to above, hybridity and interculturalism are typically viewed as an avenue to overcome and facilitate difference and alter power dynamics within social or national structures. Cultural mixing and multiple loyalties are praised in scholarly literature - for instance by Pnina Werbner - as "positive, creative, dialogical and situational” (Werbner 2013, 410). Culturally hybrid identities are situated, to use another quotation phrased in fashionable academic parlance, in a "vague and undetermined place" inhabited by "those who cross over, pass over, or go through the confines of the 'normal'”' (Anzaldua, 1987, 3). ${ }^{7}$ With its multilayered, de-centered and polyvocal form, Abide With Me can be seen to envision openness and societal transformation and to reflect key aspects of the new cosmopolitan view of multiculturalism, which as Benhabib argues, is "furthered by such multiple, overlapping allegiances which are sustained across communities of language, ethnicity, religion, and nationality” (Benhabib 2004, 174-175).

In other contexts, forms such as kathak can be an important signifier of long-distance Indian cultural nationalism: according to Ramsay Burt, their performance by immigrant communities in the diaspora is "one way of embodying Indian cultural traditions and Hindu moral and religious teachings, and thus to maintain a sense of roots despite the experience of displacement” (Burt, 2004, 100). But while Khan's work is not without an element of such rootedness, it gestures to a more fluid sense of identity with more varied cultural attachments.

\footnotetext{
7 Arguably, given current migration levels within the European Union and elsewhere, such "undetermined" places are increasingly becoming the norm.
} 
He not only negotiates dance forms of very different provenances - both Western and Asian - but redefines them through the artistic process. The intercultural qualities of his oeuvre reflect, in artistic terms, a new way of approaching difference and diversity in British (or more broadly Western) society. The "chaos" he alludes to in the earlier quotation is highly reminiscent of political philosopher Jeremy Waldron's description of the cosmopolitan citizen, who experiences a "pluralism internalized from the relations between individuals to the chaotic coexistence of projects, pursuits, ideas, images, and snatches of culture within an individual” (Waldron, 1995, 94). Mitra correspondingly uses the term 'selves' in the plural form to capture what she sees as Khan's rejection of a monolithic, essentialized and singular 'self' (2015, 26).

There can be little doubt that Abide With Me, like Khan's other work, celebrates pluralism and diversity. However, I shall argue that it admits of different readings depending on one's evaluation of interculturalism and the work's position within the broader ideology of the Games and their contribution to a reimagining of national identity. Like sport practices, dance discourses can negotiate issues of class and race and contribute to the construction of 'narratives of nation' in the sense outlined by Stuart Hall (see Silk 2011, 736). My discussion will shed some critical light on the work's deployment and function in the opening ceremony alongside recognition of its achievements, and thus diverge from the (largely) celebratory accounts of Khan's oeuvre in previous scholarship (see for instance Norridge 2010, Mitra 2015).

Olympic ceremonies typically celebrate national values and civic pride, and given its inclusion as the climax of the 'official' part of the event, Khan's choreography cannot be assessed separately from the Games themselves, their wider political aims and contribution to British self-representation. By conveying cultures in dialogic and relational terms and featuring Khan as the new cosmopolite - he describes himself as "always between two places” (in Zero Degrees, accompanying booklet, 7) - Abide With Me may be seen to depart from the binary and oppositional approach which had characterised several previous Olympic spectacles in which the 'other', as Tomlinson remarks, was “often reframed and homogenized into a series of bland costumes” (2005, 90). As a case in point, the 1984 Los Angeles Games were critizised for "marginalizing minorities and celebrating the dominant culture" (Tomlinson 1996, 592), seeking in the climate of the Cold War to "assert the superiority of the Western, capitalist, free American way” (ibid, 585). Similarly, Teresa Housel argues that 
the 2000 Sydney Games, while ostensibly embracing multicultural themes, silenced narratives of Aboriginal identity and history and eclipsed non-hegemonic forms of nationhood, thus subtly reasserting white hegemony (Housel 2007, 452).

The London bid for the Games under the banner had featured multiple ethnicities in contrast to the allegedly "all-male, all-white” (Lee 2010, 5) Paris delegation, their closest competitor. The Games were organized under a banner of "multiculturalism, diversity and inclusion across social classes” (ibid), committed to the involvement of urban youth - particularly from disadvantaged areas of East London - and aiming to create a tangible legacy. As Olympic Minister Tessa Jowell of the then-ruling Labour Party pronounced, "we define ourselves increasingly in terms of our common values - fairness, openness and tolerance. [...] And it was this spirit of inclusive British cultural identity that won us the right to host the Olympics” (2006, cited in MacRury and Poynter 2010).

The inclusive Olympics agenda, with its presentation of London as a global and diverse metropolis, distanced itself from any associations of Britishness with the class system or empire (MacRury and Poynter 2010, 4). Consequently, the Games showcased individuals such as Somali-born British athlete Mo Farah alongside Khan who were not "understood as isolated within national boundaries but as deeply and globally interrelated” (Arxer 2008, 182). In this respect it was aligned with the findings of the 400-page Parekh report published in 2000, named after its Chair, Labour peer Bhikhu Parekh, which addressed issues of identity, pluralism and social cohesion and recommended a re-imagining of Britishness which shed "old values and ancient hierarchies" that relied on "a narrow, English-dominated, backward-looking definition of the nation” (Parekh 2000, 14-15).

The Opening Ceremony merged the showcasing of (some) transnational, diasporic and hybrid identities with optimistic and arguably utopian qualities, evident in its title, "Isles of Wonder”. The artistic director Boyle described it as encompassing "a single golden thread of purpose - the idea of Jerusalem - of the better world"; and one that "can be built through the prosperity of industry, through the caring nation that built the welfare state, through the joyous energy of popular culture, through the dream of universal communication" (quoted in Biressi \& Nunn, 2013, 117, my emphasis). These “world-building” aspects were rendered through the ceremony's central sections, beginning with bucolic, rural-idyll images of an agricultural Britain followed by (somewhat more critically-painted) scenes depicting the 
Industrial Revolution to represent prosperous industries. The "caring nation” was expressed in the positive portrayal of the UK's National Health Service, and samples of British popular entertainment, film and music - incorporating Rowan Atkinson, Daniel Craig and several pop stars - stood for “joyous energy”.

We may assume that the "dream of universal communication" was intended to be conveyed through the use of dance as a non-verbal language, as the ceremony culminated in Khan's choreography. Similar notions have elsewhere been associated with Khan's work. The Rumi Foundation, one of his company's sponsors, claims that he "unites people around the universal language of dance” by mixing Indian and Western forms (Rumi Foundation, 2011), while the choreographer himself has maintained that: "Dance is a universal language of movement” (Khan 2007). The 'mortality' theme clearly constituted a common experience of all humans regardless of culture and nationality - and his positive message about the regenerative power of humankind was imparted through the final, globally comprehensible image of the boy reaching for the sky. Khan's contribution to the progressive image of the 'good society' projected by Boyle reflected New Labour policy, but also poignantly complemented "the principles of Olympism in so far as the latter seeks to rise above the narrow interests and outlook of nationalism and promote universal humanistic values” (MacRury and Poynter, 2010, 2962).

I contend that Khan's work can also be viewed as a choreographic rendition of the "world in a city” slogan (see Winter 2013) with which London had promoted its Olympic bid, and which exemplified the reconciliation of civic unity with cultural diversity as befits a multiculturalist worldview. Unity is evident in Abide With Me with its movements' execution in unison and canon. At the beginning the fifty dancers appear closely grouped together, hunched over and with knees bent, in front of an artificial sun, and all but one (the central performer closest to the camera, who remains hunched) simultaneously throw dust into the air before leaving their arms stretched out momentarily while the dust disperses creating a dramatic visual image. In another section, they execute movements in canon in a long line, standing up from a kneeling position whilst whirling their arms from left to right. The choreography deploys many formations that appear to symbolise oneness - roughly geometrical figures such as lines, a large circle and several small ones reminding spectators of the Olympic rings. The dancers, both male and female, wear virtually identical freeflowing red costumes except for Khan who is attired in a cream-coloured pair of trousers and 
shirt, and the boy whose outfit is similar to the choreographer's. The overall impression, one could argue, is that of harmony, further emphasized by the final scene in which the boy is raised aloft by the amassed group, with his right arm extended - portraying an almost triumphant image of hope and futurity.

On the other hand, some of the work's elements also emphasise diversity. The medium-angle camera shots show a mix of dancers of differing ethnicities, ages and heights. The geometrical formations mentioned above are not realised in a strict sense - instead, they are suggested or approximated. They lack the exact and perfect symmetry associated, for instance, with classical ballet repertoire, in that for instance the lines are intentionally not quite straight or a little amorphous. The angular gestures, pronounced back-bends, Khan's swirling wild arm movements and occasional feelings of tension in the piece - for instance when the group divides into two parts their movements to face one other - do not invoke harmony in the way a European theatre audience would naturally construe it. The power and mass of bodies in the group is often disrupted, or counterpointed, by an individual dancer as at the very beginning, and by Khan and the boy who are the central figures in the dance but whose steps are entirely distinctive. Even within the group work, a certain individualism is retained despite the performers' similar movements - perhaps akin to modern dance practices.

The choreographer's hybrid 'unity in diversity' approach can be seen as inclusive and progressive; as negotiating the difficult balance between universal values and the voice of the 'other' by moving “in and out of disruption and unity” (Prickett 2013, 141) and resisting the polarisation of identities seen in other Olympic ceremonies. However, criticisms levelled from various quarters at the Games' ideological framework casts doubt over their multiculturalist credentials and representation of ethnic minorities in particular, and Khan's contribution cannot fully be disassociated from the overall branding and political tone of the Opening Ceremony. From the populist right, Aidan Burley - a Conservative MP who had previously been dismissed as a ministerial aide for attending a stag party with a Nazi theme tweeted just minutes after Boyle’s section of the ceremony had ended: "Thank God the athletes have arrived! Now we can move on from leftie multicultural crap. Bring back red arrows, Shakespeare and the Stones!” (Watt 2012). While Downing Street distanced themselves from this statement, it served as a reminder of growing dissatisfaction in some circles with the 'official' celebration of cultural diversity of which the Olympics were part 
and parcel. This countervailing trend could also be seen in the growing success and visibility of the right-wing UK Independence Party, notably under the leadership of Nigel Farage from 2006.

While we might be quick to dismiss extreme views such as Burley's, other kinds of doubts about the Games have been raised in a number of scholarly sources. Falcous and Silk (2010, 178) argue that the presentation of certain individuals as 'ideal' multicultural subjects (of whom Khan and Mo Farah can be seen as examples) was a means of promoting a self-image of the nation as inclusive and diverse. Yet it veiled the fact that the event's main stakeholders were white and conservative, exemplified most prominently by Sir Sebastian Coe, the Chairman of the London Organising Committee (a former athlete and Conservative life-peer). In a similar vein, we might point to Boris Johnson who (as we know with hindsight) morphed from the face of the intercultural Olympics as London Mayor into a leading figure of the 2016 campaign to leave the EU and subsequently, a hardline eurosceptic Foreign Secretary.

The same authors also note the uncomfortable contrast between the rhetoric presenting London (and by implication the UK as a whole) as a community celebrating its diversity, and the media and political reactions following the 7/7 bombings. Commentary in both tabloid and more upmarket newspapers after the attack evoked images of the resilience and unity shown during the World War Two Blitz, invoking the spirit of a much more culturally homogenous era and implicitly pitting a unified 'us' (a civilised Western nation with a common past) against an evil and disruptive 'other' (British-born Muslim terrorists). Identifying inadequate cultural integration in Britain as a key reason behind the attack, such discourse placed Muslim Britons in "a liminal space” (ibid, 175) far removed from the possibility of intercultural dialogue. Aaron Winter (2013) goes as far as suggesting that the backlash against multiculturalism in the wake of 7/7 and the shift in government from New Labour to the Conservative-led coalition paved the way for a double-edged message in the Opening Ceremony, which prioritised hegemonic signifiers of historic national identity over what he sees as more tokenistic and limited allusions to racial or cultural difference. Its eventual agenda, according to Winter, “includes immigrants and black and minority ethnic individuals based on a logic of integration and performance that does not threaten, criticise or make demands of more traditional visions of Britishness” (Winter 2013). 
While Winter's fairly negative account might be difficult to square with the prominence given to Khan's dance work, there has been considerable debate about the ramifications of the public profile given to outstanding achievers from ethnic minority backgrounds (such as Khan, or leading sportspersons) in forums like the Olympics where they become national representatives. In her influential article on "Pride Politics and multiculturalist citizenship" (already published some time before the 2012 Games), Anne-Marie Fortier argues that these people's 'adoption' as national icons is partly a strategy for "sanitising the attachment to the nation under a veneer of guiltless pride” $(2005,566)$. On her account, such citizens are called upon - explicitly or implicitly - to declare their attachment to the nation (in this case Britain) and thereby furnish it with a seal of approval as a "tolerant and inclusive society" with “opportunities offered to all” (ibis, 569).

But the fact that they are required to make declarations of this kind amounts to a form of “deracination” (ibis, 570) in which their racial identity is substituted for a national one (or perhaps a hybrid such as "black-British” or “Asian-British”; ibid, 571). The effect of this process, intentionally or otherwise, is to emphasise further their difference from the norm (i.e. white-British), as their acceptance as national figures requires a special demonstration of allegiance, rather than being seen as something natural or automatic. Accordingly, the positioning of Khan as choreographer and lead dancer in the Olympic Ceremony may not following Fortier - undermine traditional conceptions of British identity so much as assuaging colonial guilt (by asserting the country's inclusivity) while paradoxically reinscribing the image of a nation which, while open to contributions and talents from other races and cultures, is predominantly white.

This critical perspective is at odds with Mitra's suggestion that Khan's oeuvre manages successfully to destabilise "white mainstream culture from within" $(2015,26)$ by "providing a parallel counter-narrative that is specific to non-white diasporic lives inaccessible to the majority of his audience members" (ibid). Some might feel that this claim is overly optimistic or even elitist, with such counter-narratives most likely to appeal to those individuals or groups who are already open or enthusiastic as regards cultural mixing, and so 'preaching to the converted'. Yet on the other hand, Fortier's sceptical view leads to a conundrum: taking her arguments to their logical extreme, any attempt to foster diversity by foregrounding artists from ethnic minorities may be deemed futile as it further highlights the already marginalised status of their group. Khan's Olympic choreography reached a worldwide audience, was 
officially endorsed and broadcast a powerful message of inclusivity both through its content and the choice of messenger. In broadcasting a clear statement of the benefits of multicultural society, it was in these respects surely a significant moment of British cultural expression.

\section{Lloyd Newson's Can We Talk About This? and the Critique of Multiculturalism}

While the 2012 London Games presented the world with an enthusiastic perspective on multiculturalism, it concurrently came under increasing attack from members of the public, media and even politicians in the UK and beyond. In Germany, Thilo Sarrazin's 2010 book on the failures of immigration policy, aptly titled Deutschland schafft sich ab: Wie wir unser Land aufs Spiel setzen (Germany Abolishes Itself - how we are jeopardizing our country) shot into the bestseller lists, selling over one million copies and sparking a nationwide debate. British Prime Minister David Cameron’s speech at the Munich Security Conference in 2011 echoed Angela Merkel's concerns, voiced in 2010, about the problems of multiculturalism: in particular a lack of integration and alleged 'weakening of our collective identity' (Cameron 2011). Hence while Britain was proudly advertising the virtues of its multiculturalism on the global stage, this was simultaneously being decried - in an equally public forum - as failing and as disruptive to the social order. Cameron argued that:

Under the doctrine of state multiculturalism, we have encouraged different cultures to live separate lives apart from each other and apart from the mainstream. We failed to provide a vision of society to which they feel they wanted to belong. We have even tolerated these segregated communities behaving in ways that run completely counter to our values. (ibid.)

Scepticism about multiculturalism also found its way into contemporary dance. In Can We Talk About This? (2011/12) by Lloyd Newson's DV8, criticism was levelled at the failure of Western liberal societies sufficiently to condemn militant Islamism or manage the challenges posed by certain practices in Muslim communities. A complex and contentious piece assuming prior political and current affairs knowledge, it catalogues wrongs purportedly committed in the name of religion including honour crimes against women, violations of free speech and intolerance towards other religions or heterodox sexualities. Featuring six male and four female dancers of different ethnicities and religions (including Muslims), the 80- 
minute verbatim ${ }^{8}$ physical theatre work juxtaposes over twenty scenes depicting and commenting on various incidents and conflicts. These scenes are based on, and use the testimony of, interviews with a range of prominent commentators on multiculturalism and specifically on Islam, ranging from activist Ayaan Hirsi Ali to novelist Salman Rushdie, high-profile British and Continental European politicians, academic Usama Hasan (who faced vociferous opposition and harassment over the suggestion that Darwinism was incompatible with Islam) as well as historians and journalists. Alongside verbal commentary and movement, Newson employs multiple media such as real-life TV footage and other documentary-type material. He includes voices from across the political spectrum, including Geert Wilders, the leader of the Dutch right-wing nationalist Party for Freedom, Anjem Choudary from the (now prohibited) radical Islamist group Islam4UK, as well as left-liberal figures from both the (Middle) East and West.

The work starts with a provocation. The audience see a lone performer, Hannes Langolf, clad in everyday clothes in muted colours (a pair of trousers and shirt under a pullover) leaning against a cream-coloured stage backdrop with an inbuilt door near the backstage area. To his left, pinned to the wall, is a panel of mirrors through which we can make out the audience, and in which the audience can see their images reflected. Initially in a fairly relaxed leaning posture with his front to the audience and hands on his pockets, Langolf then lifts his left leg placing it across his right, while his right arm extends above his head and his left points downward over his flexed knee. He subsequently places both arms on his legs with his fingers interlocked, conveying the image of sitting comfortably on a chair while we recognise the position as actually being quite arduous to hold. He begins to speak by directing an uncomfortable question at the audience: "Do you feel morally superior to the Taliban? Hands up if you feel morally superior to the Taliban!” (Scene: Martin Amis 2012). Not many hands go up (a fact which we can witness through the mirrors) - and the audience are immediately admonished by Langolf who pronounces himself superior to the Taliban, before telling of the plight of suppressed women in Taliban-occupied territories while slithering awkwardly against the wall.

\footnotetext{
${ }^{8}$ By the term verbatim theatre I understand a form of performance, usually with socio-political intent, which relies primarily on the selective use of transcripts and recordings of interviews (a subcategory of documentary theatre).
} 
This scene references the celebrated British author Martin Amis, who asked his audience the same question at a discussion at the London Institute of Contemporary Arts in 2007 and challenged "the first rule of cultural relativism" (as Christopher Balme puts it; 2014, 195), namely not to claim moral superiority to others. Amis later expanded thus on his own viewpoint:

Multiculturalism, I believe, is a fraud [...] We cannot justify these things [e.g., honour killings] because they're traditional. The tradition has to go [...] The Archbishop of Canterbury has been saying that sharia law should apply in various parts of the U.K. No! You don't give an inch on that. The law of the land is the law of the land. (Amis 2009)

Both in its political stance and its use of movement, the opening passage of Can We Talk About This? captures in nuce the entire work's message. Politically, it rejects the restrictions on free speech resulting from 'political correctness' and the fear of being labelled intolerant or prejudiced, and condemns the adoption of parallel sets of rules and customs by some minority groups which promote particularist interests at the expense of universal liberal values such as human rights. These phenomena are, it is suggested, the unintended consequences of a misguided form of cultural tolerance, or as Newson claims a "liberal blind spot” stemming from "post-colonial guilt” (Newson 2012). As he further expounds:

Understandably multicultural policies were initially introduced to combat racism, discrimination, promote cross-cultural understanding and encourage a sense of shared citizenship. However, these same policies have also enabled over 80 Sharia Councils to operate within Britain. These Councils, or courts, do not offer Muslim women the same rights as Muslim men. (ibid.)

The movement here and elsewhere in Can We Talk About This? is unusual, even taking into account the versatile and diverse range of the contemporary dance and physical theatre repertory. I am not convinced by Balme’s description of it as 'virtuosic' (2014, 195), at least in the most obvious sense of technical bravura. Granted, a number of scenes showcase highly trained bodies with strength, suppleness and a pronounced sense of balance. Many sections, however, draw from everyday movements which are pedestrian in nature (such as running), isolate body parts (for instance, turning the head right, left and upwards) or rely heavily on gestural elements. There are also some fleeting allusions to Middle Eastern dance forms, and many movements are stylised or performed at high speed, reflecting the breakneck tempo with which the political commentaries are juxtaposed. 
The work's originality lies partly in the way the movement underpins the spoken text. It does so neither exclusively through literal translation into physical action, nor by exteriorising emotions as in modern dance, nor indeed by drawing on a balletic vocabulary of rhetorical affects. As Hannes Langolf explains:

The movement language is not always an obvious translation of the spoken word. Often it's more an underlying commentary or it helps highlight the character and tone of the speech. It is important that the movement supports what the interviewees are saying, to lend a poetic strength in order to distinguish characters, highlight important information and drive their argument forward. (see Bahl 2011)

In the opening scene, Langolf's movements conjure up imagery of a round-table discussion in which he initially assumes a 'seated' position. The mirrors invite the spectators to look at themselves as they are asked to reflect on their own political stance. The performer's more awkward and defensive movements following his initially relaxed posture are open to interpretation, but could plausibly relate to Amis' discomfort at allegations of Islamophobia from his university colleague, cultural theorist Terry Eagleton, and others (see Kennedy 2007). The explanation in DV8's media portal refers to the "physical metaphor" of “cover[ing] your back” (Scene: Martin Amis 2012) in the face of the hostility Amis faced from his audience at the Institute of Contemporary Art.

The sceptical view of multiculturalism advanced in Can We Talk About This? may be unusual in the liberal environment of the performing arts, but does reflect a significant strand of recent scholarly, not to mention political opinion. ${ }^{9}$ In contrast with the original inclusive conception of multiculturalism as "fighting discrimination and promoting social understanding, whilst overall fighting racism” (Grau 2008, 236), scholars have expressed concern over the particularism and exclusivity associated with cultural identity politics. According to Austrian philosopher and cultural critic, Boris Buden:

As it is [sic] well known, multiculturalism is based on the concept of the uniqueness and originality of cultural formations. [...] From this perspective multiculturalism challenges the very idea of universality, for it sees every universal concept as culturally relative. There is no universal culture, but a plurality of different cultures either tolerantly recognizing or violently excluding each other [...] (Buden 2006)

\footnotetext{
${ }^{9}$ This project's affinity with English journalist Nick Cohen's You Can't Read This Book: Censorship in an Age of Freedom (2012), which not only bears a similar title but also examines comparable issues of censorship and free speech, is noteworthy.
} 
Similarly, in his 2007 online essay “The failures of multiculturalism”, Kenan Malik draws a distinction between multiculturalism as a lived reality (the 'melting-pot' society which exposes people to different lifestyles, belief systems, cuisines or art-forms), and a "prescription for the management of such diversity" (2007) through multiculturalist policies. It is the latter that concern Malik. Such policies, he argues, often follow from an assumption that cultures exist in pure original forms and, as such, are fixed entities. To change them "would be to undermine the very dignity" (2007) of their members, whose identities they have shaped. Malik sees this view as comparable to Herder's idea of the authenticity and uniqueness of national cultures; a stance diametrically opposed to the Enlightenment ideal of universal truths intelligible through reason. Malik goes on to argue that:

Multiculturalism as a political process [...] limits the extent to which people can absorb different experiences. It also undermines the possibility of dialogue and debate, by dividing society into fixed cultures and by imposing rigid identities upon the individuals who "belong" to each culture. And, in the name of "tolerance" and "respect", multiculturalism seeks to limit the kinds of clashes and conflicts necessary for a vibrant political culture. (Malik 2007)

Understood in this way, multiculturalism may undermine the very values of openness to others, mixing and hybridity that many of its advocates espouse. It is instructive, in this context, to recall French philosopher Jacques Rancière's (2011) conception of democracy, which accepts friction and tension as a desirable part of the social fabric rather than attempting to unite all elements of the community in a harmonious totality. Democratic politics, by this account, involves a break or dissensus from the established order, defined against a backdrop of consensus. Multiculturalism as described by Malik would foreclose the possibility of clashes and conflicts and inhibit negotiations between competing moral or political perspectives, preferring as does to maintain the separation and distinctiveness of cultures and their associated values and lifestyles. Paradoxically, then, it may represent an antithesis to democracy in Rancière's sense, rather than an expression or manifestation of it.

Newson's work seems aesthetically to mirror the tensions in Rancière's version of democracy, returning repeatedly to issues of political friction or disagreement: those all too often not 'talked about', as the title implies, in multiculturalist discourse. In contrast to Khan's Abide With Me where physicalities, cultures and dance vocabularies are seamlessly merged to create a hybrid fusion, Can We Talk About This? uses a collage technique as its 
main organizing strategy, both through the collocation of scenes and the selective cutting and pasting of interview material. The work's structure thus appears fragmented and disjunctive, perhaps mirroring a societal model that has become internally separated and incoherent. Khan's piece appeals primarily to the emotions, with the dramatic effects of dance and music, dense symbolisms of light and dust, bright colour schemes and movements performed in unison or canon conveying an image of harmony. Newson, by contrast, embraces what in the context of postdramatic theatre Hans-Thies Lehmann has called the "irruption of the real" (2006, 100). The tradition of verbatim theatre on which he draws, underpinned by the use of real-life TV footage, is often used to give an authentic voice or platform to a silenced or marginalized individual or group. In this case, however, the group is not - or at least not primarily - the cultural minority per se, but those who oppose or interrogate the multiculturalist orthodoxy that has become, as Newson seems to imply, an assumed majority perspective. Newson's strategy is also reminiscent of Brechtian techniques of didactic and distancing, which appeal primarily to the cognitive faculties and challenge the audience's preconceptions. Examples include the direct address at the start which breaks down the invisible 'fourth wall', the self-containment of the scenes, and the performers writing their names on the backstage wall prior to the commencement of each (recalling Brecht's technique of holding up signs or placards with information). Stage and costumes are dominated by grey and beige colours, mostly muted, and as the political activist Katwala noted, the performers' "contorted limbs embod[y] the liberal dilemmas of tolerance" (Katwala 2012).

The following sections will examine two scenes from Newson's piece, as case studies dealing respectively with topics of women's rights and freedom of the press. The first features former Labour MP Ann Cryer who represents a politically left-leaning voice; the second considers the 'Danish cartoons' controversy with the portrayal of Flemming Rose, culture editor of the Jyllands-Posten newspaper. In analysing these scenes, I shall pay close attention to their movement vocabulary as well as the verbal commentaries.

\section{Ann Cryer and forced marriages}

This four-minute scene is based on an interview with the semi-retired politician, and heralds one of the work's central topic clusters, namely the treatment of women within some minority cultures. This section focuses specifically on the issue of forced marriage, while 
associated topics introduced later in the piece include honour killings and the high suicide rate among Pakistani women. The Cryer scene is accompanied by soft piano music and features an on-stage duet between a male performer (Lee Davern) and a female (Joy Constantinides) who embodies Cryer. The stage is mostly bare, save for a simple table upstage left, and the politician appears as a mature, somewhat frail-looking woman whose feminine qualities are emphasised by her pink top and gentle manner of speech. Upon entering, she writes her name on the backstage wall and walks downstage, where the male dancer passes her a coffee cup and saucer. These props lend the scene an aura of domesticity, perhaps alluding to the interview being held in Cryer's own home. He then lifts her and places her body on his left shoulder, where she comes to rest in a sitting position still holding the cup, and begins telling the audience about her battle to bring political attention to forced marriages and the need for greater integration including use of the English language in Southeast Asian communities:

In February 1999, I raised the question of forced marriage in the House of Commons. It was the first time the issue of forced marriages had ever been raised in Parliament. And this was '99! No-one had ever mentioned it before. We didn't even call it forced marriages, because we knew we'd get an enormous amount of flack. I think we called it community relations. I remember all too well the criticism that was levelled at me. I was told by many - men in particular - that forced marriages did not exist, that they were a figment of my imagination, or an excuse to simply demonise the Asian community. [...] I was called a racist and all sorts of things, despite the fact that everything I said was said to protect the most vulnerable members of the Pakistani community, and to some extent the Bangladeshi community in my constituency. [...] Other MPs [...] dare not raise it - because it was too - let's use that horrible word sensitive, too sensitive. (Scene: Ann Cryer 2012)

This speech provides a snapshot of the thrust of Newson's more general argument, questioning whether minority groups have the right to enact cultural practices which violate the rights of their individual members, and whether, by protecting minority cultures from criticism, such practices are inadvertently condoned. As the choreographer himself stated in an interview at the piece's premiere in Sydney:

My concern sometimes, under the umbrella of tolerance, we will accept views from minorities that we would not accept from extremists within white British society. [...] Religions, like any set of ideas and philosophy, are open for debate, especially, and this is where my position is, especially where those beliefs oppress others. (Newson 2012a)

While the dancer playing Cryer herself makes only minimal movements throughout the scene, and is often manipulated by the male performer, the positions into which she is placed 
while rendering her monologue require stamina, strength and balance. In one passage the male dancer lies flat on his back as she sits (seemingly dominantly) on his legs, before he manoeuvres her to stand upright until she is balanced in a precarious position on his hands as she still holds the cup and saucer. This pose is accompanied by an offstage voice recounting allegations of racism against Cryer and her defence against them. I read her fragile position as signifying the precariousness of her political one, with the physical stamina shown replicating the psychological strength needed to fight for her cause in the face of opposition. The fact that (apart from the manipulative male dancer) she appears alone on a bare stage could refer to the loneliness, and lack of support, experienced during her campaign: she states at one point that "it was a lonely road”. The male performer's handling of her may allude to her dismissive treatment by some men as mentioned above, although the predominant image of her hovering above him might suggest her ultimate victory, or simply that her arguments 'won't go away'. DV8's online comments on the scene explain the meaning of the movement in broader party-political terms:

[T]he manipulation of the female performer and her manipulation of the male performer represent the ever-present and delicate tensions in politics between the elected (elevated) member, their supporters, and their detractors (i.e. those who would have you removed from your seat); all the while, everyone is balancing (toeing) the party line.

At the end of the scene, the audience see Cryer seated on the male dancer's back while he slowly exits to the left, crawling on his knees. The start of this movement coincides with her spoken comment "I am allergic to the word sensitive as it usually means shut up, actually" just as her character is ‘shut up’ by being carried offstage.

Epilogue: In the end - far from being shut up - Ann Cryer's campaign in Parliament helped set in motion a paradigm shift in British attitudes to honour-based crimes, which over the last two decades "transitioned from a marginal community concern to a mainstream social policy issue” (Julios 2015, 75). The FMU recorded nearly 1500 cases of Forced Marriages in 2012 (ibid, 5), although the real figure is likely to be much higher. New initiatives and legislation about honour-crimes included the creation of the Forced Marriage Unit (FMU) in 2005, a joint Home Office and Foreign and Commonwealth Office body which operates a public helpline, training programmes and media campaigns, and the eventual criminalisation of forced marriage when the 2014 Anti-Social Behaviour, Crime and Policing Act came into force. 
The Danish cartoons controversy

In September 2005, Danish newspaper Jyllands-Posten published twelve cartoon drawings sent in response to a letter from culture editor Flemming Rose inviting illustrators to "draw Muhammad, as you see him”. Rose was seeking to establish how many artists would agree to participate in this; and to what extent the fear of retribution, or "self-censorship motivated by political correctness” (Klausen 2009, 13) would prove off-putting. Many, though not all, the submitted illustrations depicted Muhammad, although some chose to criticise the newspaper itself. The image which sparked the greatest controversy, by cartoonist Kurt Westergaard, showed Muhammad as a terrorist with a bomb in his turban and a lighted fuse. This was seen as portraying the Prophet as a source of violence and associating Islam directly with terrorism. Another drawing showed five stick figures with eyes and mouths represented by stars and crescent moons (an emblem of the Ottoman Empire), possibly depicting women in Islamic dress complaining to the unseen Prophet about female suppression.

The drawings caused an initially local crisis which escalated, as Muslims took to the street in protest across Asia and Europe. Danish and other Western embassies were attacked, a fatwa was issued demanding the death of the cartoonists, and up to an estimated two hundred people died as a direct consequence of the publication - mostly in street violence. The main cause of the anger was seemingly not the religious injunction against pictorial representation of the Prophet (although this may have upset more conservative-minded Muslims) but primarily the perceived insult against the Muslim minority population and the Islamic faith. Legal expert Robert Post points out that some of the drawings did "invoke stereotypic criticisms of Islam. They comment on Islamic repression of women; the use of Islamic fundamentalist doctrines to foster violence, and the fear of violent reprisal for publishing criticism of Islam” (Post 2007, 83). According to Post (ibid, 72), the issue at stake was not primarily legal (freedom of speech versus incitement of racial hatred) but fundamentally ethical (the balance between free speech and respect for others). The impact of the drawings was augmented by an accompanying commentary by Carsten Juste, then editor-in-chief of Jyllands-Posten, which talked about "mad mullahs” hailing from "a dark and violent middle age” (quoted in Klausen 2009, 13), and which especially for those unaware of the local 
context (misogynist speeches by two provincial Muslim clerics) may have read as straightforward defamation.

A four-minute solo section of Newson's work is based on interview material with Flemming Rose, and deals with one of the choreographer's foremost themes: the perceived conflict between freedom of speech and sensitivities around religious faith. Newson specifically focuses on the effects of the cartoon controversy on the journalist himself, which included grave concerns over his safety and his life. Throughout the entire scene, the dancer portraying Rose moves in a narrow, confined space in a lit corner of the stage, the rest of which is cast in darkness. The set is dominated by greyish colours, conveying a distinct aura of tension. The camera angles change often, oscillating between high-angle shots which make the character appear vulnerable and submissive, wide shots which allow full view of his movements, and medium shots centred on his facial expression and upper body. The frequency and abruptness with which they alternate exudes a sense of nervousness and instability, supplementing the performer's own edginess at the start of the scene when he glances around as if looking out for a potential assailant.

The accompanying monologue is preceded by an offstage voice which, addressing the character of Rose, informs the audience of security cameras and bodyguards protecting his person. Rose then complains that:

Unfortunately, there are people who think that a cartoon is worth a human life. Since 2008, there have been eight separate planned attacks on me [...]. I received emails that threatened violence and killing me. [...] We don't publish Kurt Westergaard's cartoons any more in the paper because we are afraid. We feel intimidated. It means that violence works. But it's not ordinary Muslims who commit that kind of violence. I believe that the publication of the cartoons in fact had a positive impact in making it clear to Danish society that Muslims are not just speaking with one voice. [...] It's the challenging of religion and our verbal attacks and criticism of Christianity that have paved the way for Enlightenment and liberal democracies. And why should we treat Islam with another standard? It's a paradox that we welcome diversity when it comes to culture, but we do not welcome the same diversity when it comes to speech, the diversity of views. (Scene: Flemming Rose, 2012)

In movement and scenographic terms, the scene emphasises danger. Rose's legs are almost invariably in a bent position, with his feet typically flexed. He maintains almost permanent contact with the wall: sitting and leaning on it, stretching out his arms along it, or performing a handstand with his legs against it. This, combined with his equally close proximity to the 
floor in rolling and anxious slithering movements (for instance coinciding with the words "because we are afraid") suggests he is in hiding, restricting his visibility by minimising the surface that can be seen and potentially targeted. His movements, whilst at times acrobatic, are mostly minimalist and task-oriented. His costume, similarly, reflects his vulnerability: initially he appears clad in a simple beige-coloured jumper, underwear and socks, all in muted colours, with just one shoe - perhaps a reference to his wearing a panic button on his heel. DV8's online description of the scene refers to the range of movements performed upside down, with the dancer often standing on his hands, suggesting that this refers to his world being turned on its head (scene: Flemming Rose 2012).

In assessing this passage, it is important to explore how Newson approaches the issue of free speech and human rights more generally, particularly in the light of some criticisms made of his piece, notably for its alleged failure to offer a balanced perspective. When I saw the piece live in Berlin in autumn 2011, it received standing ovations. But it is as contentious as it is seen to be courageous, with press coverage being divided. While the Australian TimeOut (Saffir 2011) and Financial Times (Hemming 2012) lauded the company's courage in addressing thorny issues, the UK’s Guardian newspaper criticised the show as oversimplified and as failing to address the everyday, peaceful practice of religious observance: "What is never explored is the idea that integration in some areas of life can be combined with preservation of one's cultural and religious identity" (Billington 2012). Katwala (2012) and Malik (2012) ${ }^{10}$ argue that it is overly biased in favour of critics of multiculturalism and insufficiently critical of right-wing populists such as Geert Wilders and Ray Honeyford, and even some derogatory comments on Islam made by the author Martin Amis. It arguably underplays the voices of secular, mainstream and moderate Muslims, as Katwala claims: “[e]xcept for feminist challenges to both fundamentalism and, for some, Islam itself, nobody speaks for millions of Muslims who can and do combine a sincere faith with their belief in the rule of law in liberal democracies" (Katwala 2012). Commenting on such criticism, however, Balme points out that in a theatre work, "perfect argumentative equilibrium is perhaps not strictly necessary” $(2014,198)$, thus framing the issue as one of artistic license rather than simply free speech in the political realm.

${ }^{10}$ The interesting and publicly led exchange of opinion between Malik - one of the show's original interviewees - and Lloyd Newson is detailed by Christopher Balme (2014). 
The Flemming Rose scene deploys various elements of performance - movement, verbal commentary and camerawork - to depict the journalist's victimisation, his suffering at the hands of (extreme) Muslims and the adverse ramifications of the newspaper's defence of free speech. He is also shown as respectful of the laws of Islam - his character speaks of taking off his shoes when visiting Mosques and performs the action whilst in a handstand - but he reiterates his reciprocal expectation that national laws be respected outside of religious contexts. What is not addressed is the experience of discrimination by the European Muslim minority community through unwarranted assumptions and stereotypes; an issue highlighted by Western critics such as Klausen and Post and sections of the Islamic community itself.

An eloquently phrased blog by an American Muslim, Reza Aslan, contends that the cartoons were "intentionally inflammatory, published to further humiliate an ethnic and religious minority that has been socially and economically repressed for decades”. This marginalisation has in turn "fed the isolationism and destructive behavior of European Muslims, which has then reinforced European prejudices against Islam”. Aslan concludes that "[a]s international human rights law recognizes, in any democratic society freedom of the press must be properly balanced with civic responsibility” (Aslan 2006). This is interesting as it uses an argument based on human rights against the cartoons' publication, rather than (as Rose does) in favour of them. Shireen Azam (2015) concurs, adding that freedom of speech does not extend to the ability to publish criticism (e.g. of Islam) which is based not on genuine conviction or concern about the faith, but simply to 'experiment' with the consequences of such publication or test a community's limits by offering it gratuitous offence:

Critique squirms in an abstraction of words and images which need not have conviction in what it says [...] This fact is precisely the reason detractors of the cartoon condemn the cartoon, since Muslims already face stereotypical representations because of the paranoia surrounding Islamic terrorism and such incidents in the name of "critique" further increase the bias. It can be said that many of the cartoons' detractors do not have a fundamental problem with the cartoons or the mocking of religion, instead the problem is that the cartoons reiterate existing power imbalances in society [...] (Azam 2015)

We might add to Azam's point that the Islamic community in Denmark (and Western countries more generally) is a minority group and thus especially vulnerable to stereotyping, discrimination and feelings of disenfranchisement, and that the geopolitical balance of military and economic power continues to compromise states with majority Muslim 
populations. It may be instructive elsewhere to compare the cartoon controversy with cases involving Christian artworks which share certain similarities, such as the furore around Andres Serrano's Piss Christ (1989): a photograph of a crucifix immersed in the artist's urine which led to accusations of disrespect for Christian faith and, according to Serrano, to death threats (Fusco 2002). While the ensuing debate ushered in a discussion over the censorship of art, and the degree to which moral judgements are pertinent to works which cause offence to a group’s fundamental beliefs and values, the Danish cartoons might still be seen as different given the specific socio-political context of Islamic faith within Western countries.

Epilogue: In late 2015, a message was posted on the DV8 website announcing that Newson was to take a break from work and put his company on hold. In The Australian newspaper he cited among his reasons “a growing fear from many quarters to take risks” (Newson, cited in Albert 2016). Reiterating and justifying the main political arguments of Can We Talk About This? he was further quoted as saying that: “[T]he liberal attempt to protect minorities does them an injustice, it infantilises them. It closes down important debate” (ibid). He went on to point to issues of "free speech and censorship within the arts", perhaps in a sideswipe against the BBC which had apparently refused to film his production and continue their past collaboration with the choreographer. At least by this British institution, the main question and premise of his work - namely whether we can talk about this - had been answered in the negative.

\section{Conclusion:}

This paper has examined how Akram Khan and Lloyd Newson present highly ideologically driven yet contrasting approaches to multicultural society which resonate with major divisions in political circles and indeed in public opinion. Taken side by side, the two choreographies are highly significant contributions to the discourse on multiculturalism in the UK, and by extension the Western world. By intermixing elements of different performance traditions, Khan's work seeks to create an inter- or cross-cultural dialogue; promoting commonalities and a model of egalitarian cultural exchange that emphasises inclusion and fluidity. This reflects not only UK policy objectives (particularly under New Labour) but also the tenor of most academic discourse. Lloyd Newson, by contrast, seeks to demonstrate how multiculturalism's insistence on a plurality of cultures runs the risk of a segmented society and corrosion of human rights. 
However, it is important to note subtle nuances as these two choreographies do not simply represent positions in favour of and against multiculturalism. Khan’s aesthetic may be read specifically as reflecting a cosmopolitan view of multicultural society (akin to Delanty's), while Newson's work primarily takes issue with the particularist model. Different aesthetic strategies are used to convey these perspectives. Khan offers a highly symbolic, abstract and emotionally charged interpretation of his universal theme of mortality, centered on the figures of the choreographer himself and the young boy. Newson's approach is more scientific, employing ethnographic research to collect, organise and synthesise interview data and adapt them to construct a physical theatre work in a collage-like structure. It makes claims to truth and authority by taking a cognitive approach to its subject matter.

Both the Opening Ceremony (and by association Khan's dance segment) and Can We Talk About This? have elicited criticism. Broadcast on a global stage as part of a multimedia spectacle and officially representative of the British nation, the ceremony could be seen as a utopian construct: benign in its celebration of unity in diversity, but disputable as to whether its message echoed genuine sentiments in the UK population as a whole. The Brexit vote, the ongoing fearmongering over the 'Islamicisation' of British urban spaces, and the recent reported increase in hate crimes all suggest a less inclusive picture. Boris Johnson, one of the Olympics' public faces as then London Mayor, appears to have changed sides and now stands firmly in the pro-Brexit camp. With the benefit of hindsight, there seems a significant and possibly widening gap between most artistic (and scholarly) discourse and wider public opinion on the benefits of cultural mixing; and one should recall that even at the time of the event, the Games were charged with idealising minorities while veiling white, male hegemonic power structures. Newson's work, for its own part, has been criticised for mounting a one-sided argument which fails to acknowledge the merits of multiculturalism. The rationale for focusing exclusively on Muslim culture and politics as targets while overlooking other challenges in multicultural society is also questionable. Yet whatever one's views on the matter, Newson's critical stance has undoubtedly been resonant in many media and political discourses.

The period around the London Olympics appeared to many contemporary observers as the beginning of an era of pluralism, pride in diversity and cultural openness. Retrospectively, it might be seen to have heralded the end of such an era, or at least a time of significant challenge to multiculturalist values. Both pieces considered here also raise poignant questions 
about the UK's future direction. We have yet to see how far the trend towards state-sponsored integrationist policies will continue, and how Britishness might be (re)configured, following Brexit, both in performance and society.

\section{Bibliography:}

Akram Khan. 2014. Interview at Dancetheater.gr. https://www.youtube.com/watch?v=LwnWlCuTftk [26 June 2016].

Albert, Jane. 2016. Why Lloyd Newson put UK Dance Company DV8 on hold. The Australian. June 16. https://www.theaustralian.com.au/arts/stage/why-lloyd-newson-put-ukdance-company-dv8-on-hold/news-story/a0196d24d1773319d974fb78e967ae5b [19 April 2018].

Amis, Martin. 2009. Martin Amis versus the Taliban. Interview with Amis conducted by Margaret Wente. November $13^{\text {th }}$. https://www.theglobeandmail.com/arts/books-andmedia/martin-amis-versus-the-taliban/article4292642/ [13 ${ }^{\text {th }}$ October 2017].

Aslan, Reza. 2006. Depicting Mohammed. Why I'm offended by the Danish cartoons of the prophet. $8^{\text {th }}$ February. http://www.slate.com/human-interest/2018/03/why-rupauls-anti-transcomments-were-such-a-train-wreck.html [10th March 2018].

Azam, Shireen. 2015. The Violence of Secular Critique Understanding 'critique' in the Danish Cartoon Controversy. A Thesis submitted for the Degree of Masters in Religion and the Public Domain, University of Groningen. http://ggw.studenttheses.ub.rug.nl/81/1/1415RPD\%20\%20AZAM\%20S.\%20\%20Ma-scriptie.pdf [11 ${ }^{\text {th }}$ March 2018].

Bahl, Ankur. 2011. Interviews with performers; Ankur Bahl in conversation with Hannes Langolf and Seeta Patel. November. https://www.dv8.co.uk/media-portal/explore-ourwork/can-we-talk-about-this/hear-from-the-performers [30th October 2017].

Balme, Christopher. 2014. The theatrical public sphere. Cambridge: Cambridge University Press.

Benhabib, S. 2004. The Rights of Cultures: Aliens, Residents and Citizens. Cambridge: Cambridge University Press.

Bhabha, Homi. 1996. Culture's In-Between. In: Questions of Cultural Identity. Edited by Stuart Hall and Paul Du Gay. London: Sage, 53-60.

Big Dance Pledge website. Undated. http://www.bigdance.org.uk/big-dance-pledge [23 June 2016]. 
Billington, Michael. 2012. Can We Talk About This? - review. $13^{\text {th }}$ March. The Guardian [online]. https://www.theguardian.com/stage/2012/mar/13/can-we-talk-about-this-review [5th January 2018].

Biressi, Anita \& Nunn, Heather. 2013: Class and contemporary British Culture. Basingstoke: Palgrave MacMillan.

Booth, Robert, Dodd, Vikram, Parveen, Nazia. 2016. Labour MP Jo Cox dies after having been shot and stabbed. Theguardian [Online]. 16 June. https://www.theguardian.com/uknews/2016/jun/16/labour-mp-jo-cox-shot-in-west-yorkshire [23 June 2016].

Booth, Robert, Dodd, Vikram, Rawlinson, Kevin and Slawson, Nicola. 2016. Jo Cox murder suspect tells court his name is 'death to traitors, freedom for Britain'. Theguardian [Online]. 18 June. https://www.theguardian.com/uk-news/2016/jun/18/thomas-mair-charged-with-ofmp-jo-cox [8 August 2016].

Burt, Ramsay. 2004. Kaash: Dance, Sculpture and the Visual, Visual Culture in Britain 5(2): 93-108.

Cameron, David. 2011. Cameron: State multiculturalism has failed. https://www.youtube.com/watch?v=z3xsnEzA8Fw [18 ${ }^{\text {th }}$ February 2018].

Chin, Daryl. 1989. Interculturalism, Postmodernism, Pluralism, Performing Arts Journal (11/3 \& 12/1) The Interculturalism Issue, 163-175.

Cools, Guy. 2015. In-between Dance Cultures. On the Migratory Artistic identity of Sidi Larbi Cherkaoui and Akram Khan. Amsterdam: Valiz.

Curtice, John. 2016. Numbers tell a tale of two countries. The Times. June 25th, 19.

Delanty, Gerard. 2006. The cosmopolitan imagination: critical cosmopolitanism and social theory. The British Journal of Sociology 57(1), 25-47.

Denby, David. 2005. Herder: Culture, anthropology and the Enlightenment. History of the Human Sciences 18(1), 55-76.

Falcous, Mark and Silk, Michael. 2010. Olympic Bidding, Multicultural Nationalism, Terror, and the Epistomological Violence of 'Making Britain Proud'. Studies in Ethnicity and Nationalism 10(2), 167-186.

Fortier, Anne-Marie. 2005. Pride politics and multiculturalist citizenship. Ethnic and Racial Studies 28(3), 559-578.

Fusco, Coco. 2002. Shooting the Klan: An Interview with Andres Serrano. Communityartsnetwork. Reading room. https://web.archive.org/web/20090913054209/http://www.communityarts.net:80/readingroo m/archivefiles/2002/09/shooting the kl.php [12 March 2018].

Grau, Andrée. 2008. Dance and the Shifting Sands of Multiculturalism. In: Dance: 
Transcending Borders. Edited by Urmimala Sarkar Munsi. New Delhi: Tulika Books, 232252.

Hemming, Sarah. 2012. Can We Talk About This? National Theatre, London. Financial Times. March 13. https://www.ft.com/content/53af1d6e-6d03-11e1-a7c7-00144feab49a [3 november 2017].

Herder, Johann Gottfried von. 1969. Herder on Social and Political Culture. Translated by F.M. Barnard. Cambridge University Press.

Herder, Johann Gottfried von. 1998. Materials for the Philosophy of the History of Mankind, 1784. Internet Modern History Sourcebook. https://sourcebooks.fordham.edu/mod/1784herder-mankind.asp $\quad[24$ March 2018].

Heywood, Andrew. 2012. Political Ideologies: An Introduction. $5^{\text {th }}$ edition. Basingstoke, Hampshire: Palgrave Macmillan.

Housel, Teresa. 2007. Australian Nationalism and Globalization: Narratives of the Nation in the 2000 Sydney Olympics' Opening Ceremony, Critical Studies in Media Communication, 24:5, 446-461.

Jaggi, Maya. 2010. A Life in Dance: Akram Khan. Theguardian $27^{\text {th }}$ September. [Online]. https://www.theguardian.com/culture/2010/sep/27/akram-khan-dance-life [26 June 2016).

Jowitt, Deborah. 2003. 'In my end is my beginning', Village Voice, 15-21October. [Online] http://www.villagevoice.com/arts/in-my-end-is-my-beginning-7141103 (17 June 2016).

Katwala, Sunder. 2012. How to hear one side of an argument: The missing voices of a sledgehammer polemic. $14^{\text {th }}$ March. Open Democracy UK. https://www.opendemocracy.net/ourkingdom/sunder-katwala/how-to-hear-one-side-ofargument-missing-voices-of-sledgehammer-polemic [12 March 2018].

Kennedy, Maev. 2007. Enough, says Amis, in Eagleton feud. The Guardian online. 13 October. https://www.theguardian.com/uk/2007/oct/13/highereducation.islam [30 May 2018].

Khan, Akram 2007. Akram Khan Appoints Kallaway To Lead International PR and Sponsorship Programme. http://mediacentre.kallaway.co.uk/akram-khan-press1-print.htm [18 June 2017].

Klausen, Jytte. 2009. The Cartoons that Shook the World. New Haven, Conn./London: Yale University Press.

Lee, Mike. 2010. Case Study: How We Won the Bid. HLST Learning Legacies. https://www.heacademy.ac.uk/sites/default/files/how_we_won_the_bid.pdf [10 June 2017].

Lehmann, Hans-Thies. 2006. Postdramatic Theatre. London/New York: Routledge.

Liu, Wei Chen Roger. 2010. Global Universalism or Diasporic Particularism? An Analysis of Akram Khan's "If Not, Why Not? In: Beyond Imagined Uniqueness: Nationalisms in 
Contemporary Perspectives. Edited by Glass, William \& Burbick, Joan. Newcastle: Cambridge Scholars Publishing, 305-320.

MacRury, Ian and Gavin Poynter. 2010. 'Team GB' and London 2012: The Paradox of National and Global Identities. The International Journal of the History of Sport 27: 16-18, 2958-2975.

Mackrell, Judith. 2012. MoveTube: Why Akram Khan will command the Olympic stadium. Theguardian 27th July. [Online]. https://www.theguardian.com/stage/2012/jul/27/movetubeakram-khan-olympic-dance [26 June 2016].

Malik, Kenan. 2007. The Failures of Multiculturalism. The Secular State and Islam in Europe. Available online: http://www.kenanmalik.com/papers/engelsberg mc.html [4 April 2017].

Malik, Kenan. 2012. We should talk about this. Pandaemonium. March 18. https://kenanmalik.wordpress.com/2012/03/18/we-should-talk-about-this/ [3 October 2017].

Mitra, Royona. 2015. Akram Khan: Dancing New Interculturalism. Basingstoke, Hampshire: Palgrave Macmillan.

Newson, Lloyd. 2012a. World Premiere DV8 Physical Theatre - Can We Talk About This? https://www.youtube.com/watch?v=5NlOPzP4UM8\&t=61s [24 August 2016].

Newson, Lloyd. 2012. Can We Talk About This? A Closer Look... Foreword from Artistic Director, Lloyd Newson. March. [Part of the educational pack provided by DV8]. https://www.dv8.co.uk/media-portal/explore-our-work/can-we-talk-about-this.

Norridge, Zoe. 2010. Dancing the Multicultural Conversation? Critical Responses to Akram Khan's Work in the Context of Pluralist Poetics, Forum for Modern Language Studies, 46(4), 416-429.

Nussbaum, Martha. 1997. Cultivating Humanity. A Classical Defense of Reform in Liberal Education. Cambridge: Harvard University Press.

Nussbaum, Martha. 2006. Patriotism and Cosmopolitanism, in Twentieth Century Political Theory. A Reader. Edited by Stephen Bronner. New York: Routledge.

Parekh Report. The Future of Multi-Ethnic Britain. Report of the Commission on the Future of Multi-Ethnic Britain. Established by the Runnymede Trust. Chair: Bikhu Parekh. London: Profile Books.

Pavis, Patrice. 1996. Introduction. In The Intercultural Performance Reader. Edited by Patrice Pavis, 1-21. London and New York: Routledge.

Phillips, Trevor. 2005. Let's Show the World Its Future. theguardian [Online]. 10 July. https://www.theguardian.com/uk/2005/jul/10/olympics2012.olympicgames [11 July 2016].

Post, Robert. 2007. Religion and Freedom of Speech: Portraits of Muhammad. Constellations 14(1), 72-90. 
Prickett, Stacey. 2013. Embodied Politics: Dance, protest and identities. Hampshire: Dance Books.

Rancière, Jacques. 2011. “Does Democracy Mean Something?” In Dissensus: On Politics and Aesthetics, edited by Steven Corcoran, 45-60. London: Continuum.

Rofli, Norliza. 2012. Researching Hybridity In Dance: Realizing 1 Malaysia, in Dancing Mosaic: Issues on dance hybridity. Edited by Mohd Anis Md Nor. Kuala Lumpur Cultural Centre, University of Malaya National Department for Culture and Arts, Ministry of Information, Communication and Culture, 9-16.

Rushdie, Salman. 1991. Imaginary Homelands: Essays and Criticism 1981-1991. New York: Penguin.

Razaq, Rashid. 2016. Sadiq Khan: I'll take the arts as seriously as housing and crime. Evening Standard [online]. http://www.standard.co.uk/news/london/sadiq-khan-ill-take-thearts-as-seriously-as-housing-and-crime-a3252086.html) [23 June 2016].

Saffir, Rebecca. 2011. Review of Can We Talk About this? 26 August. http://www.au.timeout.com/sydney/theatre/events/25736/can-we-talk-about-this

December 2016].

Scene: Martin Amis. 2012. Rehearsal footage from Can We Talk About This?, directed by Lloyd Newson. Available on DV8 Physical Theatre website. https://www.dv8.co.uk/mediaportal/explore-our-videos/martin-amis [4 March 2018].

Scene: Ann Cryer. 2012. 2012. Rehearsal footage from Can We Talk About This?, directed by Lloyd Newson. Available on DV8 Physical Theatre website. https://www.dv8.co.uk/media-portal/explore-our-videos/ann-cryer [4 March 2018].

Scene: Flemming Rose. 2012. Rehearsal footage from Can We Talk About This?, directed by Lloyd Newson. Available on DV8 Physical Theatre website. https://www.dv8.co.uk/mediaportal/explore-our-videos/flemming-rose [4 March 2018]

Silk, Michael. 2011. Towards a sociological analysis of London 2012, Sociology, Special Issue: Sociology and the 2012 Olympic Games, 45(5) p. 733-748.

Spratt, Sasha. 2016. Sadiq Khan backs Big Dance Pledge. London Live. http://www.londonlive.co.uk/news/2016-05-19/sadiq-khan-backs-big-dance-pledge [18 June 2016].

Tomlinson, Alan. 1996. Olympic spectacle: opening ceremonies and some paradoxes of globalization. Media, Culture \& Society 18, 583-602.

Tomlinson, Alan. 2005. Picturing the Winter Olympics: The Opening Ceremonies of Nagano (Japan) 1998 and Salt Lake City (USA) 2002. Tourism, Culture \& Communication, Vol. 5 pp. 83-92. 
The Rumi Foundation. 2011. Akram Khan Dance Company. October. http://rumifoundation.com/journal/akram-khan-dance-company/ [11 July 2016].

Tran, Mark. 2005. London celebrates Olympics decision. Theguardian. [Online]. 6 July. https://www.theguardian.com/uk/2005/jul/06/olympics2012.olympicgames3 [23 June 2016].

Waldron, Jeremy. 1995. Minority Cultures and the Cosmopolitan Alternative. In The Rights of Minority Cultures, edited by Will Kymlicka. Oxford: Oxford University Press, 93-122.

Watt, Nicholas. 2012. Olympics opening ceremony was 'multicultural crap', Tory MP tweets. Theguardian [online]. 28 July. http://www.theguardian.com/politics/2012/jul/28/olympicsopening-ceremony-multicultural-crap-tory-mp [13 August 2016].

Werbner, Pnina. 2013. Everyday multiculturalism: Theorising the difference between 'intersectionality' and 'multiple identities'. Ethnicities 13(4), 401-419.

Winter, Aaron. 2013. Race, Multiculturalism and the 'Progressive' Politics of London 2012: Passing the 'Boyle Test' Sociological Research Online, 18 (2) 18, http://www.socresonline.org.uk/18/2/18.html [11 April 2018].

Zero Degrees. 2008. Sadler's Wells on Screen. (Accompanying booklet). Akram Khan, Sidi Larbi Cherkaoui, Antony Gormley and Nitin Sawhney. Axiom Films and Sadler's Wells Trust. 